\title{
Obituary: John Harold Wallis
}

In this obituary by Michael Wallis (BMJ 2011;342:d3876, doi:10.1136/bmj.d3876) John Harold Wallis was in partnership for 33 years, not three years as published. We apologise for this error, which we did not pick up when the obituary was retyped for processing.

Cite this as: $B M J 2011 ; 343: d 4872$ 